\section{Social Work}

\section{\& Education}

(c) SW\&E, 2018

Kateryna Chervonenko, teacher of the Department of Social Work,

Municipal Institution of Higher Education «Khortytska National Educational Rehabilitation,

Academy» of Zaporizhzhia Regional Council,

Zaporizhzhya, Ukraine,

kschervonenko@ukr.net

\section{Катерина Червоненко,} викладач кафедри сочіальної роботи,

Комунальний вищий навчальний заклад «Хортииька національна навчально-реабілітаційна академія» Запорізької обласної ради,

м. Запоріжж, Україна.

УДК 378.02:37.016

DOI: $10.25128 / 2520-6230.18 .1 .8$

Article history:

Received: Febuary 27, 2018

1st Revision: March 20, 2018

Accepted: March 31, 2018
Chervonenko, K. (2018). Зміст і структура готовності майбутніх соціальних працівників до організації волонтерської діяльності учнівської молоді, Social Work and Education, Vol. 5, No. 1., pp. 79-87.

\section{ЗМICT I СТРУКТУРА ГОТОВНОСТI МАЙБУТНІХ СОЦІАЛЬНИХ ПРАЦІВНИКІВ ДО ОРГАНІЗАЦІЇ ВОЛОНТЕРСЬКОЇ ДІЯЛЬНОСТІ УЧНІВСЬКОЇ МОЛОДІ}

АНОТАЦІЯ. У статті актуалізована проблема формування готовності майбутніх соціальних працівників до організації волонтерської діяльності учнівської молоді, як одна із складових їх професійної підготовки. У контексті здійснюваного дослідження розглянуто тлумачення категорії «готовність» та «професійна готовність» у довідковій та енциклопедичній літературі, а також наведені визначення вітчизняних $\mathrm{i}$ зарубіжних дослідників. Поняття «готовність» $\epsilon$ складним багатовимірним поняттям 3 певними пізнавальними, вольовими, мотиваційними та емоційними характеристиками. «Професійну готовність» розглядають з позиції фахової підготовки майбутніх фахівців як фундаментальну умову їх успішної самостійної професійної діяльності.

Розглянуто зміст формування готовності майбутніх соціальних працівників до різних видів професійної діяльності. Визначено основні аспекти формування готовності майбутніх соціальних працівників до організації волонтерської діяльності учнівської молоді: позитивне ставлення, стійке бажання; наявність комплексу знань, практичних вмінь та особистого досвіду щодо планування, організації, управління, реалізації, оцінювання та прогнозування. Наголошено на тому, що волонтерська діяльність майбутніх соціальних працівників дозволяє їм набувати досвід здійснення соціально-значимої діяльності.

Сформульовано визначення поняття «готовність майбутніх соціальних працівників до організації волонтерської діяльності учнівської молоді» та розкрито зміст і компоненти готовності до здійснення такого виду діяльності: ціннісно-мотиваційний, особистісний, когнітивний, операційний, рефлексивнооцінний.

Ключові слова: готовність; професійна готовність; готовність до організації волонтерської діяльності; соціальний працівник; волонтерська діяльність; компоненти готовності. 


\section{Вступ}

Активний розвиток у соціально-економічній, освітній, медичній та культурній сферах призводить до необхідності здійснення реформ, спрямованих на радикальні зміни у всіх сферах життя сучасного суспільства. Це сприяє підвищенню вимог до якості професійної підготовки фахівців, зокрема соціальних працівників, професійна компетентність яких вимагає розширення їх професійних інтересів та функцій у сфері організації та здійснення волонтерської діяльності. Майбутні фахівці соціальної сфери мають володіти якісними знаннями, вмінням проектувати, планувати, самостійно вирішувати складні завдання та надавати кваліфіковану допомогу, вмінням організовувати взаємодію 3 організаціями та суспільством, адекватно оцінювати результативність своєї допомоги та прогнозувати подальші шляхи іiі удосконалення. Події сьогодення, пов'язані 3 наслідками військового конфлікту на сході країни, доводять, що важливе місце у системі підготовки соціальних працівників займає проблема формування їх готовності до організації волонтерської діяльності учнівської молоді, оскільки формувати особистість майбутнього волонтера необхідно вже у період навчання у старшій школі.

\section{Аналіз останніх публікацій}

Проблемам професійної підготовки соціальних працівників присвячена велика кількість наукових доробок. Так, загальні теоретичні та методологічні аспекти професійної підготовки соціальних працівників представлено в роботах таких вчених: С. Архипова, М. Галагузова, А. Капська, В. Поліщук, Л. Тюптя та ін.; особливості професійної підготовки майбутніх соціальних працівників в умовах університетської освіти розглянуті у роботах О. Карпенко; становлення соціального працівника як професіонала розкриті у наукових дослідженнях В. Бочарової, А. Ляшенко, В. Поліщук; формуванню особистісних рис соціального працівника присвячені доробки В. Бех, I. Пінчук, І. Мигович та ін. Характеристика готовності до здійснення різних видів професійної діяльності представлена у роботах О. Водяної, Т. Голубенко, Д. Данко, Ю. Рябової, Р. Санжаєвої та ін.

Заслуговують на особливу увагу праці, в яких висвітлюються особливості підготовки студентів до реалізації різних форм волонтерства, серед яких виділяються дослідження О. Акімової, О. Богданової, Л. Вандишевої, Т. Лях, 3. Бондаренко та ін., які вивчали особливості організації волонтерської діяльності серед студентства. Проте, незважаючи на численні доробки сучасних вчених, проблема формування готовності майбутніх соціальних працівників до організації волонтерської діяльності учнівської молоді $є$ малодослідженою і потребує подальшого вивчення.

Метою статті $\epsilon$ визначення змісту та структурних компонентів готовності майбутніх соціальних працівників до організації волонтерської діяльності учнівської молоді. 


\section{Завдання статті передбачають:}

- розкриття суті понять «готовність», «професійна готовність», «Готовність майбутніх соціальних працівників до організації волонтерської діяльності учнівської молоді»;

- визначення та розкритття змісту компонентів готовності майбутніх соціальних працівників до організації волонтерської діяльності учнівської молоді».

\section{Методологія дослідження}

Для досягнення мети було використано комплекс теоретичних методів дослідження: аналіз, синтез, порівняння та узагальнення існуючих наукових досліджень 3 проблеми формування готовності майбутніх соціальних працівників до організації волонтерської діяльності учнівської молоді. Аналіз та синтез дозволив розглядати поняття «готовність до організації волонтерської діяльності» через визначення основних категорій, покладених в їх основу та встановлювати їх взаємозв'язок. Порівняння використовувалося для співставлення характеристик готовності майбутніх соціальних працівників до здійснення різних напрямків професійної діяльності. Узагальнення дозволило встановити характерні особливості готовності майбутніх соціальних працівників до організації волонтерської діяльності учнівської молоді та на їх основі визначити її структуру.

\section{Основна частина}

Професійна підготовка майбутніх соціальних працівників органічно пов'язана $з$ проблемою формування їх готовності до здійснення професійної діяльності в різних сферах, в тому числі і в сфері волонтерства.

Проблема формування готовності була предметом дослідження психології та педагогіки впродовж декількох століть, проте єдиної думки щодо трактування поняття «Готовність» на сьогодні не існує.

Довідкова й енциклопедична література тлумачить категорію «готовність» як:

- активно-дієвий стан особистості, установка на певну поведінку, змобілізованість сил для виконання завдання (Коропуліна В., 2006, с. 57 );

- пристосування можливостей особистості для успішних дій у даний момент, внутрішне налаштування особистості на певну поведінку при виконанні задач, установку на активні та цілеспрямовані дії; систему інтегративних якостей, властивостей, знань, навичок особистості (Гончаренко С., Зязюн І., Ничкало Н., 2000, с. 74);

- високий рівень розвитку мотиваційних, пізнавальних, емоційних та вольових процесів особистості, колективу, який забезпечує успіх майбутньої діяльності (Ярмаченко М., 2001, с. 58);

- стан мобілізації психологічних і психофізичних систем людини, які забезпечують виконання певної діяльності (Кремень В., 2008, с. 137);

Підтвердженням багатоаспектності трактування поняття «готовність», виступають твердження вітчизняних та зарубіжних дослідників, які визначають готовність як: 
- якість особистості, психічний стан, що інтегрує попередньо засвоєні установки, знання, уміння, навички, досвід, характеристики й мотиви діяльності; психологічна налаштованість на виконання діяльності (Дяченко М., Кандибович Л., 1976, с. 36);

- змінна характеристика, складне багаторівневе утворення, особистісна цілісна властивість, усталена внутрішня структура якостей та здібностей особистості, що реалізуються в діяльності та залежать від віку, досвіду, індивідуальних особливостей особистості (Дзюба-Шпурик Л., 2016, с. 79).

- загальна психологічна сталість, спрямованість на діяльність будь-якого виду, наявність якостей для самовдосконалення особистості в майбутньому (Можаровська О., 2016, с. 22).

- цілісне стійке особистісне утворення, яке характеризується емоційнокогнітивною та вольовою мобілізацією суб'єкта в момент включення його в певний вид діяльності (Линенко А., 1996, с.17).

Аналіз наукових досліджень показав, що готовність виступає складним багатовимірним поняттям 3 певними пізнавальними, вольовими, мотиваційними та емоційними характеристиками. Вона виступає фундаментальною умовою якісного здійснення будь-якої діяльності, а іiі формування відбувається безпосередньо в процесі цілеспрямованої діяльності та позитивної налаштованості на неї. 3 огляду на подані вище трактування поняття «готовність» в енциклопедичній літературі, словниках i, поділяючи погляди дослідників, ми дійшли висновку, що готовність це інтегративна особистісна здатність до здійснення конкретної діяльності, яка складається 3 обов'язкових знань, умінь, навичок, здібностей, якостей та властивостей.

Готовність найчастіше розглядається як результат професійної підготовки фахівців до здійснення певної діяльності та визначається як основна умова пї успішного виконання. Тому поряд 3 поняттям «готовність» важливого значення набуває розгляд та уточнення поняття «професійна готовність».

Професійну готовність дослідники (О. Дубасенюк, О. Безпалько, О. Можаровська, В. Поліщук, Н. Гендіна. В. Шеремет та ін.) розглядають з позиції фахової підготовки майбутніх фахівців і трактують ії як інтегративну складну характеристику особистості, що визначається як сукупність професійних якостей, необхідних і достатніх для успішної самостійної професійної діяльності. Готовність не може бути природженою якістю, лише як набута властивість особистості.

В Енциклопедії освіти детально виокремлено кілька аспектів готовності до професійної діяльності: операційний - оволодіння певним набором дій, знань, умінь та навичок; мотиваційний - як система професійних якостей щодо конкретної діяльності; соціально-психологічний - рівень сформованості комунікативної сфери особистості майбутнього спеціаліста; психофізіологічний готовність систем організму діяти в конкретно визначеному професійному напрямі (Кремень В., 2008, с. 137).

Аналіз наукових досліджень показав, що найчастіше професійну готовність розглядають як складне структурне утворення особистості, яке передбачає бажання оволодіти певною професією, сформовані знання, уміння та навички для реалізації професійної діяльності та виступає результатом професійної підготовки. 
Результатом підготовки майбутніх соціальних працівників виступає їх готовність до реалізації різних напрямків професійної діяльності у соціальній сфері.

Так, проблему готовності до соціального супроводу сімей, в яких перебувають діти під опікою, досліджувала О. Водяна, яка визначала професійну готовність як сукупність взаємопов'язаних рис (особистісних, професійних, спеціальних), досконале володіння теоретичними знаннями і практичними навичками, здатність творчо вирішувати проблемні ситуації та нести відповідальність за свої рішення, постійний саморозвиток, самовдосконалення, самоосвіта. Компонентами професійної готовності до такого виду діяльності дослідниця виділила особистісний (мотиваційна сфера, професійні якості, педагогічні здібності), теоретичний (базові та спеціальні знання) та практичний компонент (загальнопедагогічні та спеціальні вміння та навички) (Водяна О., 2014, с. 36).

Д. Данко досліджувала готовність соціальних працівників до застосування технологій медико-соціальної роботи в професійній діяльності і розглядала їі як стійке особистісне утворення, в якому інтегровані мотиви, емоції, знання й уміння майбутнього фахівця, що зумовлюють ефективне вирішення проблем, пов'язаних 3 відновленням, збереженням та зміцненням здоров’ я населення (Данко Д., 2015, с. 86).

T. Голубенко, вивчаючи проблему формування готовності майбутніх соціальних працівників до патронажної роботи з людьми похилого віку, готовність розглядала як професійну зрілість, визначаючи наступні компоненти: мотиваційноціннісний, змістово-професійний, когнітивно-операційний та практично-діяльнісний компонент (Голубенко Т., 2014, с. 197).

Важливим аспектом професійної підготовки майбутніх соціальних працівників виступає формування їх готовності до організації волонтерської діяльності, яка для студентів - майбутніх соціальних працівників - може розглядатися як квазіпрофесійна, оскільки вона гуманістична за своєю природою, спрямована на підтримку людей, які мають проблеми, пов'язана зі здійсненням життєдіяльності і сприяє набуттю студентами професійного досвіду взаємодії з ними. У широкому смислі мета соціальної роботи і волонтерської діяльності єдина і передбачає надання допомоги людям, які потрапили у складну життєву ситуацію, підвищення якості життя. Важливим аспектом схожості соціальної роботи і волонтерської діяльності виступають єдині технології роботи 3 різними категоріями населення. О.В. Богданова наголошує на тому, що волонтерська діяльність виступає різновидом професійної соціальної та соціально-педагогічної роботи і складається 3 наступних процедур: проектування, розробка та управління волонтерськими проектами, відбір, підготовка і навчання волонтерів; взаємодію з організаціями та суспільством, що здійснюють діяльність у галузі організації та управління волонтерською діяльністю (Богданова О., 2010, с. 27).

Волонтерська діяльність для майбутніх соціальних працівників виступає ресурсом особистісно-професійного розвитку, який дозволяє їм набувати досвід здійснення соціально-значимої діяльності, прояву соціальної активності та громадянської позиції, бути причетним до вирішення важливих суспільних проблем та сприяти розвитку у них практичних навичок роботи 3 різними категоріями населення, у різних напрямках. 
Організація волонтерської діяльності учнівської молоді буде забезпечувати реалізацію основних функцій соціального працівника: діагностичної, організаційної, посередницької, прогностичної, профілактичної, що сприятиме розкриттю можливостей їх удосконалення.

У контексті підготовки майбутніх соціальних працівників до організації волонтерської діяльності змістом їх готовності виступають: сформована мотивація, позитивне ставлення до волонтерської діяльності та стійке бажання ії здійснювати та залучати молодь; наявність у майбутніх соціальних працівників комплексу знань, практичних вмінь та особистого досвіду щодо організації, реалізації та керівництва діяльністю, а також особливостей іï впровадження у певній сфері суспільного життя; вміння адекватно організовувати співробітництво, вирішувати конфлікти, оцінювати результативність допомоги та прогнозувати подальші шляхи іiі удосконалення.

3 огляду на вищевикладене, готовність майбутніх соціальних працівників до організації волонтерської діяльності учнівської молоді ми будемо розглядати як здатність майбутніх соціальних працівників, яка проявляється у стійкому бажанні займатися волонтерською діяльністю, володінні спеціальними знаннями, вміннями та компетенціями щодо іiі планування, організації, управління, реалізації, оцінювання та прогнозування з представниками учнівської молоді.

Узагальнення досліджуваних матеріалів дає нам можливість визначити основні компоненти готовності майбутніх соціальних працівників до організації волонтерської діяльності учнівської молоді: ціннісно-мотиваційний, особистісний, когнітивний, операційний, рефлексивно-оцінний.

Під ціннісно-мотиваційним компонентом готовності ми будемо розуміти сукупність мотивів та інтересів в оволодінні професією у цілому та здійсненням волонтерської діяльності зокрема. Важливим складником ціннісно-мотиваційного компоненту майбутніх соціальних працівників виступають ціннісні орієнтації.

Особистісний компонент - передбачає формування професійно значущих особистісних якостей, властивостей, необхідних для організації волонтерської діяльності учнівської молоді (мобільність, здатність приймати адекватні рішення, витривалість, спостережливість, емпатія та толерантність, здатність пристосовуватись до нових умов тощо).

Когнітивний компонент - зумовлений знаннями майбутніх соціальних працівників щодо сутності та специфіки організації волонтерської діяльності учнівської молоді.

Операційний компонент - відображає сформованість спеціальних вмінь та навичок щодо організації волонтерської діяльності учнівської молоді: планування, реалізації, управління.

Рефлексивно-оцінний компонент - проявляється в здатності до аналізу та оцінювання діяльності, особистісних досягнень, самоконтролю, саморегуляції аналізу реальних ситуацій та власного саморозвитку.

\section{Висновки та перспективи подальших досліджень}

Отже, проблема готовності майбутніх соціальних працівників до організації волонтерської діяльності учнівської молоді виступає складовою частиною 
процесу фахової підготовки студентів до здійснення професійної діяльності $\mathrm{i}$ розглядається як здатність майбутніх соціальних працівників, яка проявляється у стійкому бажанні займатися волонтерською діяльністю, володінні спеціальними знаннями, вміннями та компетенціями щодо ii планування, організації, управління, реалізації, оцінювання та прогнозування з представниками учнівської молоді. Компонентна структура готовності до означеної діяльності виступає як єдність і взаємозв'язок ціннісно-мотиваційного, особистісного, когнітивного, операційного та рефлексивно-оцінного компонентів, що характеризують здатність майбутніх соціальних працівників професійно здійснювати фахову діяльність.

Перспективи подальших наукових розвідок вбачаємо у дослідженні критеріїв, показників та рівнів сформованості готовності майбутніх соціальних працівників до організації волонтерської діяльності учнівської молоді.

\section{Література}

Богданова, Е. В. (2010). Подготовка будущих социальных педагогов к волонтерской деятельности. Новосибирск: ИдеИ И Идеалы. 27-35.

Водяна, О. В. (2014). Зміст професійної готовності працівника соціальної сфери до роботи з опікунською сім'єю. Проблеми сучасної педагогічної науки. Педагогіка та психологія. Ялта: РВВ КГУ. Вип. 42. 36-41.

Голубенко, Т. О. (2014). Особливості процесу формування готовності майбутніх соціальних працівників до патронажної роботи з людьми похилого віку. Вісник ЛНУ імені Тараса Шевченка. Вип. 5 (288). 195-201.

Гончаренко, С. У., Зязюн, І. А., Ничкало, Н.Г. (2000). Професійна освіта: словник. Київ : Вища школа. 380.

Данко, Д. В. (2015). Підготовка майбутніх соціальних працівників до застосування технологій медико-соціальної роботи в професійній діяльності. (Дисертація кандидата наук). Ужгород. 278.

Дзюба-Шпурик, Л. Г. (2016). Формування готовності майбутніх учителів початкової школи до ознайомлення учнів $\mathrm{x}$ інформаційно-комунікаційними технологіями (Дисертація кандидата наук). Полтава. 295.

Дьяченко, М. И., Кандыбович, Л.А. (1976). Психологические проблемы готовности к деятельности. Москва: Изд-во БГУ. 176.

Кремень, В. Г. (2008). Енциклопедія освіти. Київ. : «Юрінком Інтер». 1040.

Копоруліна, В.М.(2006). Українсько-російський психологічний тлумачний словник. Харків : Факт. 400.

Линенко, А. (1996.) Теорія і практика формування готовності студентів педагогічних вузів до професійної діяльності: автореф. дис. на здобуття наук. ступеня. д-ра пед. наук: спец. 13.00.04. Київ. 44.

Можаровська, О. Е. (2016). Формування готовності до професійно орієнтованого іншомовного спілкування майбутніх фахівців у коледжах технічного профілю. (Дисертація кандидата наук). Вінниця. 278.

Ярмаченко, М. Д. (2001). Педагогічний словник. Київ : Пед. думка. 514. 


\title{
CONTENT AND STRUCTURE OF FUTURE SOCIAL WORKERS' READINESS TO ORGANIZE VOLUNTEER ACTIVITY
}

\author{
Kateryna Chervonenko, teacher of the Department of Social Work, Municipal \\ Institution of Higher Education «Khortytska National Educational \\ Rehabilitation Academy» of Zaporizhzhia Regional Council, \\ Zaporizhzhya, Ukraine, \\ kschervonenko@ukr.net
}

\begin{abstract}
The article is devoted to a problem of readiness formation of future social workers for implementation of pupils' volunteer activities as a part of their professional training. The purpose of this paper is to identify the basic concepts of the terms «readiness», «professional readiness», «readiness of the future social workers for the implementation of volunteer activities». The study presents the description of the content and the components of the readiness of future social workers for volunteer work. During the research, next general scientific methods have been used: theoretical analysis, synthesis, comparison and generalization.

The author considers the definitions of the concepts «readiness» and «professional readiness» in encyclopedia and reference work, gives the definitions of these concepts of domestic and foreign eminent. Based on the analysis of scientific literature, the author makes the conclusion that "readiness» is the complex concept, which has cognitive, volitional, motivational and emotional characteristics.

It is emphasized, that professional readiness is essential for successful professional activity of future specialists. The article presents the opinions of the eminent persons in social work on the content of readiness formation of future social workers for different types of professional activities. The main features of readiness formation of future social workers for implementation of pupils' volunteer activities are dwelt upon. These are: positivism and willingness; profound knowledge, practical skills and personal experience in planning, organizing, management, realization and forecasting.

The author stresses that volunteer activity is important as practice for future social workers and can help them in their socially important work. The author gives the definition of the concept «readiness of the future social workers for implementation pupils' volunteer activity» and presents the description of the content and the components of readiness for this type of activity: value-based and motivational, personal, cognitive, operational and reflective.
\end{abstract}

Keywords: readiness; professional readiness; readiness for the implementation of volunteer activities; social worker; volunteer activity; components of readiness.

\section{References}

Bogdanova E. V. (2010). Future social teachers training for volunteer activity. Novosibirsk «Ideas and Ideals». (1). 27-35. [In Russian].

Danko D. V. Preparing the future social workers for using technologies of medical and social work in the professional activity. (Candidate's thesis). Uzhorod. 278. [In Ukrainian]. 
Dyachenko, M. I., Kandybovich, L. A. (1976). Psychological problems of readiness for activity. Moscow: publishing house of BGU. 176. [In Russian].

Dziuba-Shpurik, L. G. (2016) Formation of the readiness of future social teachers for application of multimedia educational systems in school (Candidate's thesis) Poltava 295. [In Ukrainian].

Golubenko T. O. Features of readiness of the future social workers from patronage of the eldery. Bulletin of LNU named after Taras Shevchenko. Issue 5 (288). 195-201. [In Ukrainian].

Goncharenko, S. U., Nychkalo, N. G. (2000). Professional education: dictionary. Kyiv: High school. 380. [In Ukrainian].

Kremen V. G. Encyclopedia of Education. Kyiv.: «Yurinkom Inter».1040. [In Ukrainian].

Koropulina, V. M. (2006). Ukrainian - Russian Psychological Dictionary. Kharkiv: FACT. 400. [In Ukrainian].

Linenko A. F. Theory and practice of forming of ped. universities students' readiness to the professional activity: author report of dis. for getting of scientific degree of the doctor of pedagogics : speciality 13.00.04. Kyiv. 44. [In Ukrainian].

Mozharovska, O. E. (2016). Formation of readiness to professionally oriented language communication of future professionals in technical profile colleges. (Candidate's thesis). Vinnytsia. 278. [In Ukrainian].

Vodiana, O. V. Components of professional training of future specialists in the social sphere for social support of families having children in care. Pedagogy and Psychology. Yalta. RBB KGU. Issue 42. 36-41. [In Ukrainian].

Yarmachenko, M. D. (2001). Pedagogical dictionary. Kyiv: Pedahohichna dumka. 514. [In Ukrainian]. 
